HUMANIKA Vol. 19 No. 1 (2014) ISSN 1412-9418

Gender Performance in Elizabeth Gaskell's Ruth

Eta Farmacelia Nurulhady

\title{
GENDER PERFORMANCE IN ELIZABETH GASKELL'S RUTH
}

\author{
Eta Farmacelia Nurulhady \\ Fakultas Ilmu Budaya Universitas Diponegoro \\ Jl. Prof. H. Soedharto, SH Tembalang Semarang 50275 \\ Email: farmacelia@gmail.com
}

\begin{abstract}
Abstrak
Gender adalah konstruksi sosial yang mengikat anggota masyarakat tertentu untuk menampilkan perilaku yang sesuai dengan identitas gendernya. Tulisan ini bertujuan untuk mengkaji tampilan gender dalam novel Ruth karangan Elizabeth Gaskell untuk mengetahui sudut pandang Inggris di era Victoria tentang gender sebagai konstruksi sosial. Tokoh tokoh dalam novel ini harus berperilaku yang sesuai dengan identitas gender mereka. Tokoh utama, Ruth, juga dihakimi berdasarkan tampilan gendernya, dan dia harus menerima hukuman masyarakat ketika dianggap melanggar aturan sebagai seorang perempuan. Dengan usaha sadarnya untuk berperilaku sesuai dengan ekspektasi masyarakat atas seorang perempuan, Ruth berhasil mendapatkan kembali tempat yang terhormat dalam masyarakat. Dari seorang yang dianggap sebagai perempuan jalang, Ruth kemudian dikenal sebagai malaikat penolong. Ruth dipandang berdasarkan identitas gender yang ia tampilkan, dan ia menjadi seorang perempuan yang terhormat dalam masyarakat.
\end{abstract}

Kata kunci: gender, tampilan gender, konstruksi sosial

\section{INTRODUCTION}

In general, people are grouped into being male or female based not only on their physical condition but also on their social condition. This is what people usually refer to as gender. As gender is also determined by the social condition, it may also be perceived differently depending on the cultural background of a particular society. Hence, what is considered as appropriate for a certain gender in a particular society may not be the same as that in another society? Different historical periods seem to offer their own perspectives on gender related issues. One of possible sources to see such diverse perspectives on gender related issues is literary works as they are believed to reflect the condition of the society in which they are written.
An example of such literary works is Ruth, a Victorian English novel written by Elizabeth Gaskell. The heroine is Ruth, an orphan young girl who is a seamstress apprentice. Her parents die when she is still too young to understand social expectation of her as a female member of the society. Lack of parental guidance leads her to a fatal mistake that makes her become a fallen woman, which the society despises. With the help of Mr. Benson, a caring minister, Ruth repents and struggles hard to be a respectable woman. Although she finally manages to win the societyố respect, she has to pay it with her life. The major characters in the narrative not only show the notion of gender as a social construct but also perform their gender as their constructed identities. The story of Ruthô life represents Victorian English perspective on gender as a social 
construct and how members of the society must perform particular traits and acts that show their gender performance; otherwise they must bear the punitive consequences for not doing so.

\section{GENDERIN ENGLAND}

\section{VICTORIAN}

Simone de Beauvoir lays the foundation which distinguishes sex from gender when she says: ñOne is not born, but rather becomes, a womanò (1972: 267). It suggests that a woman gradually acquires her gender, an aspect of her identity, through a socially constructed experience. Judith Butler furthers Beauvoirô concept of gender by claiming that gender is not only a social construct but also ñan identity instituted through $a$ stylized repetition of acts; é a constructed identity, a performative accomplishment which the mundane social audience, including the actors themselves, come to believe and to perform in the mode of beliefơ(ñ1 988: 519-20). In other words, one is always in the process of becoming a gender rather than actually being a gender. Butler affirms: ñthe action of gender requires a performance that is repeated. This repetition is at once a reenactment and reexperiencing of a set of meanings already socially established; and it is the mundane and ritualized form of their legitimation (1990: 140). The notion of gender performance finds its application in Elizabeth Gaskellôs Ruth, including the social punishment that she has to endure. Butler asserts: ñs a strategy of survival, gender is a performance with clearly punitive consequences. Discrete genders are part of what 'humanizes' individuals within contemporary culture; indeed, those who fail to do their gender right are regularly punishedò (1988: 522).

Victorian English perspective on gender places an importance for a woman to be ñan angel in the houseò which places woman in the domestic sphere. In addition, the term, as M. Jeanne Peterson points out in her essay: ñNo Angles in the House: The Victorian Myth and the Paget Women,ò covers some notions which include being pious and suggests: ñhe angelôs domesticity, unworldlydiness, asexuality, innocence, even helplessness in matters outside the domestic sphereò (1984: 677). When a woman fails to perform the expectation, she can fall into a category of a fallen woman and needs to be sent to a penitentiary. In Victorian England, penitentiary is a reformative institution to rehabilitate female outcasts or fallen women, many of which are prostitutes. Susan Mumm in her essay on penitentiary and fallen women states: ñWho were these óow and repulsiveô women? Candidacy for a penitentiary was simple: to have fallen was to have had sexual intercourse with a man to whom one was not marriedò (1996: 529). Interestingly, the punishment applies to the woman only and not to the man who supposedly shares the same sin.

In her essay, ñSex and Gender in Simone de Beauvoirô Second Sex," Butler argues that: ก̃To be a gender, whether man, woman, or otherwise, is to be engaged in an ongoing cultural interpretation of bodies and, hence, to be dynamically positioned within a field of cultural possibilitiesò (1986: 36). This notion applies well in the narrative in which Ruth has to cope with dabyrinths of social ethicsô(1986: 33) that is, as George Watt points out in his book The Fallen Woman in the Nineteenth-Century English Novel, ñ complex network of interacting traditions, habits, and individualsò whose forces engage physical and abstract forms. The physical forms are embodied in a number of characters who condemn Ruth for being a great sinner. The abstract form is ñhe cruel social mores which demand scapegoats in the forms of fallen women and their cursed offspringò (1984: 96). 
HUMANIKA Vol. 19 No. 1 (2014) ISSN 1412-9418

Gender Performance in Elizabeth Gaskell's Ruth

Eta Farmacelia Nurulhady

\section{GENDER PERFORMANCE IN ELIZABETH GASKELL'S $\boldsymbol{R U T H}$}

The heroine of the narrative, Ruth, is a fifteen year old orphan girl when she is sent to be a seamstress apprentice under Mrs. Masonô supervision. Due to a health problem, Ruthô mother ñwas unable to bestow the ever-watchful attention to domestic affairs so requisite in a farmer's wifeò (Gaskell, 1997: 33) and died when Ruth was twelve, three years prior to Ruthô fatherôs death. Ruth is left without proper model and knowledge that a young woman of her age should have. As an apprentice, Ruth works long hours during the weekdays but is left on her own on Sundays. The other apprentice girls have friends or relatives, but Ruth has nobody. A lonely girl without loving people around her, Ruth finds Bellingham, an upper-class young gentleman, a sympathetic company. Ruth has only the slightest notion on what is expected of her gender. After an afternoon walk with Bellingham, she is puzzled by her feeling of right and wrong:

ñHow strange it is," she thought that evening, "that I should feel as if this charming afternoon's walk were, somehow, not exactly wrong, but yet as if it were not right. Why can it be? I am not defrauding Mrs. Mason of any of her time; that I know would be wrong; I am left to go where I like on Sundays. I have been to church, so it can't be because I have missed doing my dutyò (Gaskell, 1997: 37).

Having the least understanding of her gender, Ruth is not aware that her being miles away from home with a man who is not her husband is not socially acceptable. She makes further social mistake by following Bellingham and living with him after being cast away by Mrs. Mason.

Ruth does not know that she is being seduced. She only knows that being with Bellingham makes her happy. The narrator says:

She was too young when her mother died to have received any cautions or words of advice respecting the subject of a woman's life--if, indeed, wise parents ever directly speak of what, in its depth and power, cannot be put into words--which is a brooding spirit with no definite form or shape that men should know it, but which is there, and present before we have recognized and realized its existence (Gaskell, 1997: 39-40).

This passage demonstrates the notion of gender as a social construct. Ruth does not instinctively know how to become a woman. One needs to learn to be a proper gender, and Ruth lacks the required training to become one. Hilary M. Schor argues that this passage represents either love or sexuality. The fact that love and sexuality are not mentionable leads a young woman to not knowing better yet being blamed for making mistakes that she does not know. She poses a rhetorical question: ñIf Ruth cannot ớall in love,ô how can she ớallô?ò (1992: 63) However, what happens to Ruth shows that being ignorant does not exclude her from having to bear the consequence of her conduct that her society deems inappropriate.

Jemima, a girl of Ruthô age, is the first person who finds out about Ruthô real identity when everybody else sees Ruth as a respectable Mrs. Denbigh after she is brought to live in Eccleston by Mr. Benson. Jemima ponders that if she were in Ruthôs position that is without home, parents, and careful friends she would likely be tempted as well. Jemima is born and raised in an environment which enables her to become a woman, to acquire her gender through a socially constructed experience. The narrator says of Jemima: 
She had never shaped her conviction into words and sentences, but still it was there, that all the respectable, all the family and religious circumstances of her life, would hedge her in, and guard her from ever encountering the great shock of coming face to face with viceò (Gaskell, 1997: 266).

Ruth, on the other hand, does not have enough knowledge and experience to understand that.

Earlier in the narrative, women seem to be the sterner ones to judge Ruth. For example, Mrs. Mason immediately expels Ruth for being seen ñstanding with a lover, far away from home, at such a time in the eveningò (Gaskell, 1997: 48). While Ruth is still ignorant of her wrong conduct, everybody else around her has already placed their judgment. A housewife who lives near the Welsh inn where Ruth and Bellingham stay says: ñI do think itô a shame such people should be allowed to come here. To think of such wickedness under the same roofò (Gaskell, 1997: 61). It is this housewifeô little boy who hits Ruth face preventing her from kissing his baby sister because: ñShe is a bad, naughty girl ï mamma said so, she didò (Gaskell, 1997: 62). This little boy gives Ruth not only ña great blow on her faceò (Gaskell, 1997: 62) but also a new idea which initiates her to start to understand the labyrinths of social ethics and how she is seen by the society.

The narrative shows a double standard in society in regards to what happens between Bellingham and Ruth. Jenny Morgan, the innkeeper of the Welsh inn, suspects that Ruth is not Bellinghamô wife because a wife of a gentleman would have a servant with her. Yet she immediately takes it lightly: ñndeed, and young men will be young men; and as long as their fathers and mothers shut their eyes, it's none of my business to go about asking questionsò (Gaskell, 1997: 62). Jennyôs statement presupposes that it is normal for an upper-class gentleman to seduce a lower-class girl. Yet, the blame is imposed upon the woman. After forcing her son to abandon Ruth, Mrs. Bellingham states in her letter to Ruth: ñ wish to exhort you to repentance, and to remind you that you will not have your own guilt alone upon your head, but that of any young man whom you may succeed in entrapping into viceò (Gaskell, 1997: 78). Being innocent and seduced, Ruth is accused of deceiving a man into vice. Mrs. Bellingham recommends Ruth to go to penitentiary. Ruth has now been a fallen woman. Being a fallen woman, she is considered degraded and needs to reform.

Ruthôs initial encounter with harsh reality happens when she is hit by a boy who calls her a bad, naughty girl because his mother says so. Even then she does not get what it means. When Bellingham deserts her, the narrator says that Ruth: ñad no penitence, no consciousness of error or offence; no knowledge of any circumstance but that he was goneò (Gaskell, 1997: 80). Again, this refers back to the fact that her mother died when she was too young, and it leaves her with the least understanding of social ethics. Ruthôs reaction on knowing her being pregnant strengthens the notion of her ignorance of social norms and expectation. Faith Benson tells Mr. Benson: ñShe did not seem to understand how it ought to be viewed, but took it just as if she had a right to have a baby. She said, 'Oh, my God, I thank Thee! Oh, I will be so good!' I had no patience with her then, so I left the room" (Gaskell, 1997: 99). As a member of a society carrying a certain gender, Ruth is expected to understand her gender expectation. However, Ruth does not have any idea of what she has done and how she is seen in the eyes of society.

When she finds out her sonôs situation, Mrs. Bellingham insists that her son is not to be blamed because she believes that it is Ruth who is degraded. Years later, Bellingham himself still considers his seducing Ruth as his 
HUMANIKA Vol. 19 No. 1 (2014) ISSN 1412-9418

Gender Performance in Elizabeth Gaskell's Ruth

Eta Farmacelia Nurulhady

youthful follies and offers money as compensation, to which Mr. Benson sharply counters: ñMen may call such actions as yours, youthful follies! There is another name for them with God!ò (Gaskell, 1997: 371). It is a part of gender as social construct that enables man to move on with his life after making a mistake. When Bellingham can continue his life as if nothing has happened, Ruth has to bear the consequence for the rest of her life. Even Mrs. Bellinghamôs maid refuses to nurse Ruth because if she did that, she ñcould never have the face to dress a lady of character againò (Gaskell, 1997: 90). The maid suggests that a fallen woman does not have a place in society that simply by being in contact with one will corrupt a good woman.

Had Thurstan Benson, a dissenting minister, not helped her, Ruth would have gone through a darker path in her life since society has decided what should happen to a fallen woman. When asked about Ruthôs whereabouts, Mrs. Pearson, who heard about Ruth from her sister-inlaw, Mrs. Mason says:

"The girl? Why, ma'am, what could become of her? Not that I know exactly--only one knows they can but go from bad to worse, poor creatures! God forgive me, if I am speaking too transiently of such degraded women, who, after all, are a disgrace to our sex." (Gaskell, 1997: 264).

Having no chance of being accepted by society after being fallen, a woman will certainly be a prostitute for life. It is a common knowledge that Bellingham, Ruthô seducer, also thinks the same way:

Poor Ruth! And, for the first time for several years, he wondered what had become of her; though, of course, there was but one thing that could have happened, and perhaps it was as well he did not know her end, for most likely it would have made him very uncomfortable (Gaskell, 1997: 229).

To save Ruth from her social fate, Mr. Benson takes Ruth to Eccleston and gives her a new identity as Mrs. Denbigh, a widow, so that she and her son would be accepted by society.

Mr. Breadshaw, an important figure in Eccleston, asserts the need to keep up certain rules in regards to what women should and should not do and the consequence of certain actions performed by them. He ensures that his wife and daughters perform what is expected of their gender. He is pleased when he finds that his daughter, Jemima acts submissively after her previously rebellious acts. When he assumes that Jemimaô change of conduct is due to Ruthôs influence, he immediately thinks of giving better reward to Ruth:

With the fragrance of Ruth's sweetness lingering about her, Jemima was her best self during the next halfhour. Mr. Bradshaw was more and more pleased, and raised the price of the silk, which he was going to give Ruth, sixpence a yard during the time (Gaskell, 1997: 195).

Prior to that moment, Jemima has been a bad girl by always contradicting $\mathrm{Mr}$. Farquhar and her father. Based on the norms of the society, women should not have their own opinion.

A good woman in terms of her gender is like Mr. Breadshawô wife who is $\tilde{n}_{\text {sweet }}$ and gentle looking, but as if she was thoroughly broken into submissionò (Gaskell, 1997: 129). Therefore, in Mr. Farquharôs opinion, Ruth will make a better wife because: ñlovely, quiet Ruth with her low tones and quiet replies, her delicate waving movements, appeared to him the very type of what woman should be $\ddot{i}$ a calm, serene soul, fashioning the body to angelic graceò (Gaskell, 1997: 
254). Ruth as Mrs. Denbigh conforms to the Victorian stereotype of the áhe angel in the house.ô

The notion of the ñangel in the houseò is gender expectations that Ruth violates earlier that cause her to become a fallen woman. What Mr. Farquhar, and everybody else in Eccleston, sees in Ruth as Mrs. Denbigh is gender as a social construct. There are certain characteristics and expectation imposed on certain gender, and one has to have those and perform them well to be considered proper in being oneôs gender. In Eccleston, Ruth is the widow Mrs Denbigh, and she performs her gender well.

An uneducated farmerôs daughter, Ruth educates herself to be able to educate her son. She performs her new identity well that people see her as a respectable, educated woman that Mr. Breadshaw asks her to be a governess for his young daughters. With her previous and true identity, Ruth would not have accomplished such a position. She was just a poorly educated farmerôs daughter and a fallen woman as well. So well does Ruth perform her new identity that people see her as not only capable of being a governess but also suitable to be better than just being a governess. Even Bellingham sees her as a different person:

He thought this Mrs. Denbigh was certainly like poor Ruth; but this woman was far handsomer. Her face was positively Greek; and then such a proud, superb turn of her head; quite queenly! A governess in $\mathrm{Mr}$. Bradshaw's family! Why, she might be a Percy or a Howard for the grandeur of her grace! (Gaskell, 1997: 229).

Ruth as Mrs. Denbigh is no longer an innocent, naïve girl that he seduced and abandoned several years ago. Ruth performs her gender in the mode of beliefs that lead her society to believe what she performs. Ruth understands that she is a fallen woman, but she performs to be a respectful one, and she performs it in the mode of belief so that her society sees and believes what she performs.

When he is finally sure that Mrs. Denbigh is Ruth, Bellingham says to himself: ñlt certainly was Ruth; only how the devil had she played her cards so well as to be the governess--the respected governess, in such a family as $\mathrm{Mr}$. Bradshaw's?ò (Gaskell, 1997: 229) Bellingham sees what everybody else in Eccleston sees in Ruth, only he knows Ruthô background that makes it hard for him to believe what has become of Ruth then. Ruth performs her new identity so well that when Jemima first heard about Ruth being a fallen woman, she thinks:

Now, and here, there was no hypocrisy; but some time, somewhere, on the part of somebody, what hypocrisy, what lies must have been acted, if not absolutely spoken, before Ruth could have been received by them all as the sweet, gentle, girlish widow, which she remembered they had all believed Mrs. Denbigh to be when first she came among them! (Gaskell, 1997: 267-8).

Ruth performs repeated actions that confirm an established set of social meanings attached to being an ideal woman. Her gender performance wins Ruth a respectable place is society.

However, when her past is revealed, Ruth loses her job and her place in society. Her son out of sudden has to also bear the burden of being a bastard. Mr. Farquhar, who once thought to take Ruth as his wife, is relieved that he has never made his intention public. At a certain point, people pay attention more to her fall than her performance.

Ruth has to bear these punitive consequences. Mr. Breadshaw, an important figure in Eccleston, is one who strongly believes the necessity of punishment for those who violate social 
HUMANIKA Vol. 19 No. 1 (2014) ISSN 1412-9418

Gender Performance in Elizabeth Gaskell's Ruth

Eta Farmacelia Nurulhady

rules and norms. He confronts Mr. Benson who defends Ruth by alluding to Maria Magdalen. Mr. Breadshaw perseveres:

The world has decided how such women are to be treated; and, you may depend upon it, there is so much practical wisdom in the world, that its way of acting is right in the long-run, and that no one can fly in its face with impunity, unless, indeed, they stoop to deceit and imposition (Gaskell, 1997: 288).

Therefore, once he finds out that Ruth is a fallen woman, he immediately fires her and withdraws his support for her. Mr. Breadshaw, who used to see Ruth as a role model for his daughters, now sees Ruth as no more that a degraded woman who corrupts his daughtersômorality.

Ruth wins back her society because she does not give up performing her respectable gender. From a governess, she turns to become án angel of mercyô by nursing sick people, especially those from the lower class. By doing so, Ruth manages to turn around societyôs judgment. Ruthô mistake is still there, but people see Ruth in a different light. Leonard overhears people talk about his mother, and he proudly presents himself as Ruthô son:"Such a one as her has never been a great sinner; nor does she do her work as a penance, but for the love of God, and of the blessed Jesus. She will be in the light of God's countenance when you and I will be standing afar offò (Gaskell, 1997: 351). The quotation suggests that society sees a fallen woman as having a certain nature, but Ruth demonstrates that she does not have that nature. By the time Ruth dies, people have regarded her as an angelic woman. The large number of people who attend her funeral to pay their last respect shows Ruthôs success in her accomplishment. Even Mr. Breadshaw, together with his whole family, attends the funeral sermon conducted by Mr. Benson, showing her respect to Ruth and Mr. Benson whom he previously opposed.

\section{CONCLUSION}

Elizabeth Gaskellôs Ruth exemplifies the notion of gender as a social construct. The characters in the narrative perform their gender, and gender roles are also imposed on the heroine, Ruth. At the beginning Ruth is constructed as a girl and a fallen woman based on her performance even though she does not realize it due to her lack of knowledge of the social expectation of her as a female member of the society. After acquiring the knowledge of her expected gender, Ruth consciously performs a respectable woman and the society buys her gender performance. When her past as a fallen woman is exposed to public scrutiny, she is faced with punitive consequences of violating gender rules. However, her insistence in performing a respectable woman wins the societyôs trust of her and brings her the title of an angel of mercy. Ruthô identity is replaced because she is able to perform her gender well, and society believes her performance. Ruth proves that the way of behaving is the most important thing in society. Her gender identity is seen for what she behaves, i.e. what she performs. 
HUMANIKA Vol. 19 No. 1 (2014) ISSN 1412-9418

Gender Performance in Elizabeth Gaskell's Ruth

Eta Farmacelia Nurulhady

\section{REFERENCE}

Beauvoir, Simone de. (1972). The Second Sex. Trans. H.M. Parshley. New York: Penguin.

Butler, Judith. (1988). ñPerformative Acts and Gender Constitution: An Essay in Phenomenology and Feminist Theoryò. Theatre Journal. 40 (4): 519-31.

(1986). Sex and Gender in Simone de Beauvoir's The Second Sex. Yale Studies 72: 35-49.

(1990). Gender Trouble. New York: Routledge.

Gaskell, Elizabeth. (1997). Ruth. London: Penguin Books.
Mumm, Susan. (1996). ñNot Worse than Other Girlsô The Convent-Based Rehabilitation of Fallen Women in Victorian Britainò. Journal of Social History. 29 (3): 527-46.

Peterson, M. Jeanne. (1984). No Angles in the House: The Victorian Myth and the Paget Women. The American Historical Review. 89 (3): 677-708.

Schor, Hilary M. (1992). Scheherezade in the Marketplace: Elizabeth Gaskell \& the Victorian Novel. New York: Oxford University Press.

Watt, George. (1984). The Fallen Woman in the Nineteenth-Century English Novel. London: Croom Helm; Totowa, N.J.: Barnes \& Noble. 